\title{
The Impacts of Lifestyle Modification Education towards Cardiovascular Risk Profile
}

\author{
Fonny Cokro', Abdul Rahem ${ }^{2}$, Lisa Aditama ${ }^{3}$, Franciscus C. Kristianto ${ }^{3}$ \\ ${ }^{1}$ Pharmacy Study Program, Atma Jaya Catholic University of Indonesia, Jakarta, Indonesia, \\ ${ }^{2}$ Department of Clinical and Community Pharmacy, Faculty of Pharmacy, Airlangga University, \\ Surabaya, Indonesia, ${ }^{3}$ Department of Clinical and Community Pharmacy, Faculty of Pharmacy, \\ University of Surabaya, Surabaya, Indonesia
}

\begin{abstract}
Obesity is one of the risk factors of cardiovascular disease. The prevalence of obesity in Indonesia has increased in the last few years, therefore some efforts to reduce the risk is needed. In the current study, efforts are given through 3-week lifestyle modification education, with 3-month total of followup (from March to June 2014) and then the impacts on cardiovascular risk profile were observed and seen on 24 sedentary male workers in University of Surabaya with obese II. This study used before-after study design in order to see the impacts of the 3-week lifestyle modification education towards change of knowledge, dietary behavior, body mass index (BMI), waist circumference, and cardiovascular risk profile through various educational methods (face-to-face session, given recorder of face-to-face session, and combination of both methods). Statistical analysis was performed using Wilcoxon signed test. Result showed an increasing knowledge in face-to-face group $(\mathrm{p}=0.046)$. However, there were no significant changes in other variables (dietary behavior based on healthy diet indicator (HDI), BMI, waist circumference, and also cardiovascular risk profile) in all groups between before and after education intervention $(\mathrm{p}>0.05)$. In conclusion, lifestyle modification education given for 3 weeks did not reduce the cardiovascular risk profile on sedentary male workers with obese II. Longer term intervention and multicomponent program including behavior therapy may be needed to succeed lifestyle changes and reduce cardiovascular risk.
\end{abstract}

Keywords: Behaviour, cardiovascular risk, education, knowledge, lifestyle modification

\section{Pengaruh Edukasi Gaya Hidup terhadap Perubahan Risiko Penyakit Kardiovaskular}

\begin{abstract}
Abstrak
Obesitas merupakan salah satu faktor risiko penyakit kardiovaskular. Prevalensi obesitas di Indonesia mengalami peningkatan beberapa tahun terakhir, sehingga diperlukan upaya untuk menguranginya. Pada penelitian ini, upaya dilakukan melalui pemberian edukasi gaya hidup yang dilakukan selama 3 minggu, dengan total follow-up sampai dengan 3 bulan dari bulan Maret hingga Juni 2014, kemudian dilihat dan diamati ada atau tidaknya penurunan risiko penyakit kardiovaskular pada 24 orang karyawan pria obese II di Universitas Surabaya. Penelitian ini memiliki rancangan before-after study design untuk menguji pengaruh edukasi gaya hidup yang diberikan selama 3 minggu terhadap variabel pengetahuan, perubahan perilaku, body mass index (BMI), lingkar perut, dan risiko penyakit kardiovaskular melalui berbagai metode pemberian edukasi (tatap muka, rekaman/recorder, dan kombinasi). Analisis dengan Wilcoxon signed test menunjukkan bahwa terdapat peningkatan pengetahuan hanya pada subgrup tatap muka $(\mathrm{p}=0,046)$. Tidak terdapat perubahan yang signifikan terhadap variabel lainnya (perubahan perilaku berdasarkan healthy diet indicator (HDI), BMI dan lingkar perut, serta risiko penyakit kardiovaskular) pada semua subgrup antara sebelum dan sesudah edukasi $(\mathrm{p}>0,05)$. Edukasi gaya hidup yang diberikan selama tiga minggu tidak memberikan penurunan risiko penyakit kardiovaskular pada karyawan pria obese II. Dibutuhkan intervensi jangka panjang dan program multikomponen yang memuat terapi perilaku untuk menyukseskan perubahan perilaku dan menurunkan risiko kardiovaskular.
\end{abstract}

Kata kunci: Edukasi, gaya hidup, pengetahuan, perilaku, risiko kardiovaskular

Correspondence: Fonny Cokro, M.Farm-Klin., Apt., Pharmacy Study Program, Atma Jaya Catholic University of Indonesia, Jakarta 12930, Indonesia, email: fonny.cokro@atmajaya.ac.id

Received: $20^{\text {th }}$ February 2018, Accepted: 17 $7^{\text {th }}$ June 2018, Published: $1^{\text {st }}$ September 2018 


\section{Introduction}

Obesity is one of the components of metabolic syndrome. Obesity can develop metabolic effects on blood pressure, total serum cholesterol, triglyceride, and insulin resistance, therefore can increase cardiovascular disease risk. ${ }^{1}$ The prevalence of obesity in Indonesia has increased in the last few years. Based on Riskesdas 2013 data, prevalence of adults with obesity (body mass index/BMI $>25$ ) in Indonesia is $15,4 \%$. Nationally, the prevalence of central obesity is $26,6 \%$, which is higher than that in $2007(18,8 \%){ }^{2}$ Based on World Health Organization data concerning of noncommunicable disease in 2008, number of deaths caused by cardiovascular disease and diabetes in Indonesia were higher in men than in women. ${ }^{3}$ Furthermore, based on AsiaPacific Task Force, comorbidity risks were higher in obese type II (BMI $\left.\geq 30 \mathrm{~kg} / \mathrm{m}^{2}\right)$ and waist circumference $\geq 90 \mathrm{~cm}$ (in men), ${ }^{4}$ therefore intervention is needed to be given to men with obese II category and waist circumference of $\geq 90 \mathrm{~cm}$. In this study, the subjects were sedentary worker men who had higher risk developing central obesity, especially those who spent $>35-40$ hours of work per week. ${ }^{5,6}$

Lifesytle modification education is one of suitable therapies for obesity patients. Lifestyle modification is suitable for all obese subjects without concerning the risk of side effects and interaction effects gained from drugs. ${ }^{4,7}$ By having education, subjects were expected to change their lifestyle, and this lifestyle modification could possibly impact cardiovascular risk profile.

Studies stated that the weight reduction could be achieved in 3-month term. ${ }^{8,9}$ In this study, a 3-week education class was followed up to 3-month duration in order to give enough time for subjects to lose weight. This study also compared the effectiveness of various education methods, which were face-to- face session, given recorder of face-to-face session, and combination of both methods. Education method using electronic device, in this point is recorder, can be used to add number of participants. This study aimed to see the relation of various education methods towards knowledge, dietary, BMI, waist circumference, and cardiovascular risk profile.

\section{Methods}

This study was conducted according to Helsinki Declaration of 1975, and had been reviewed by Ethical Committee of University of Surabaya (Reference number 0928/UM/III/ 2014).

Design study

This study used before-after study design to see the impacts of education towards knowledge, dietary change based on healthy diet indicator (HDI), BMI and waist circumference, also cardiovascular risk profile. This study was implemented to obese II men in University of Surabaya and conducted on March-June 2014.

Subjects were given lifestyle modification and cardiovascular risk profile education. Subjects also received healthy plate, diary as self recording and education media, and also short message service (SMS) as a reminder for subjects to fill the diary. All participants received education from the same nutritionist. Education methods given were face-to-face session, recorder, and combination of both methods (sessions divided into face-to-face and recorder). Subjects who could not attend to education schedule received audio compact disc filled with education record.

Population and sample

Population in this study were all men workers with obese II category in University of Surabaya. Screened population then became sample through convenience sampling technique in order to obtain the suitable sample size, which 
were 25 subjects. The inclusion criteria were men worker in University of Surabaya with obese II category (BMI $\geq 30 \mathrm{~kg} / \mathrm{m}^{2}$, waist circumference of $>90 \mathrm{~cm}$ ), productive age of 18-64 years old, and agreed to attend lifetyle modification and cardiovascular risk profile education. Participant who did not met any inclusion criteria were excluded. Before the intervention began, informed consent was filled by all participants to ensure the safety of data privacy.

\section{Data collection}

Knowledge questionnaire was collected one time before (March 2014) and after education (June 2014). Diary form filled every day since 1 week before education intervention started, and was collected at the end of intervention. Direct interview with nutritionist was done twice before and after education intervention. Body weight, waist circumference, as well as laboratory results including HDL cholesterol and total cholesterol of subjects was examined before and after intervention. Body weight was measured using the same calibrated scale for all participants during intervention. The measurement of waist circumference was made at the approximate midpoint between lower margin of palpable rib and top of the iliac crest. Laboratory test was collected by Prodia clinical laboratory, using standardized methods of measuring indicators. Laboratory results and blood pressure were converted into cardiovascular risk profile using Framingham Risk Score.

\section{Data analysis}

Wilcoxon signed test was used to see the impacts of education towards knowledge, dietary change (based on HDI), BMI and waist circumference, and cardiovascular risk profile variable.

\section{Instruments}

Instruments used in this study were questionnaire to measure subject's knowledge, and self recording diary which was used to assess food components consumed by subjects. Human instrument in this study was a nutritionist. A direct interview was done by nutritionist to assess subjects's dietary change. Another instrument used was laboratory checking (serum HDL cholesterol and total cholesterol), and sphyghnomanometer.

Before given to all participants, knowledge questionnaire containing 19 questions and "Diet Readiness Test" containing 6 questions had been validated to 30 similar respondents using Cronbach's $\alpha$. "Diet Readiness Test" had been translated into Indonesian Language and then translated back into English by Ubaya Language Center (ULC), after that the fitness was measured. Based on Spahn's study in 1996, "Diet Readiness Test" was very useful and recommended to be used as a reference for obese patients. ${ }^{10}$

Framingham Risk Score has been widely used for predicting cardiovascular event in 10 years ahead and its validity had been proved. Framingham Risk Score calculator was used based on D'Agostino's study in 2008. This tool includes some factors contributing to cardiovascular events, including age, diabetes history, smoking habit, blood pressure, total cholesterol, and HDL category. ${ }^{11}$ The instruments used in this study which had been calibrated are body weight scale, height and waist circumference gauge, and also "OMRON" digital sphyghnomanometer.

\section{Results}

This quantitative study was done from March until June 2014. Total population was 38 men worker with obese II, and only 27 among them who fulfilled the criteria. A total of 25 among them was required to become subjects based on Slovin's formula. The 25 subjects received education intervention. During the intervention, one subject dropped out due to 
Table 1 Characteristics of Subjects

\begin{tabular}{lc}
\hline \multicolumn{1}{c}{ Demographic } & Participants \\
\hline Age (mean \pm SD) & $39.70 \pm 7.29$ \\
Body mass index (mean \pm SD) & $32.60 \pm 2.78$ \\
Wasit circumference (mean \pm SD) & $104.80 \pm 6.70$ \\
Pharmacotherapy history (routinely consumed for the last 3 months): & $1(4.17 \%)$ \\
1. Antihipertension & $4(16.67 \%)$ \\
2. Smoking habit & \\
\hline
\end{tabular}

business affair. The participants' demographic characteristics can be seen on Table 1 .

Validity and reliability results

Based on validity and reliability test results, knowledge questionnaire and "Diet Readiness Test" obtained $r>0.3$ and Cronbach's $\alpha>0.7$, hence they were fit to be used as instruments (Cronbach's $\alpha=0.819$ and 0.813 for "Diet Readiness Test" and knowledge questionnaire, respectively).

Comparison analysis of knowledge before and after education

Data analysis using Wilcoxon signed test showed that there was a significant increase in knowledge between before and after education on face-to-face session group $(\mathrm{p}<0.05)$, while on the other groups, there was no significant change $(p>0.05)$.

Comparison analysis of participants's dietary behavior (based on HDI) before and after education

Data analysis using Wilcoxon signed test showed that there was no significant change of HDI on all groups $(p>0.05)$ between before and after education.

Comparison analysis of BMI and waist circumference before and after education Data analysis using Wilcoxon signed test showed that there was no significant reduction of BMI and waist circumference on all groups $(p>0.05)$ between before and after education. Comparison analysis of cardiovascular risk profile before and after education

Data analysis using Wilcoxon signed test showed that there was no significant reduction of cardiovascular risk profile on all groups $(p>0.05)$ between before and after education intervention.

\section{Discussion}

In this study, results on face-to-face session group showed that there was a significant increase of knowledge, while other groups did not. Face-to-face session was likely to be the best method of education due to direct interaction with the subjects. This kind of interaction seems important for knowledge acceptance.

Based on the results of study, there was no dietary behavior change occurred on all groups, including face-to-face session group. According to the Information-Motivation-Behavioural Skills Model (IMB), behavior change could happen because of sufficient information and/or motivation, directly. ${ }^{12}$ All subjects in this study had passed "Diet Readiness Test" which indicated that there was motivation to reduce weight on subjects, but there was no consistency of motivation on face-to-face session group that caused the lack of dietary behavior change even if there was an increasing knowledge on the group (Figure 1).

Furthermore, no behavior change may be linked to the lack of reduction of BMI, waist circumference, and cardiovascular risk profile. In this study, it can be seen from Table 2 that there was no significant change on 


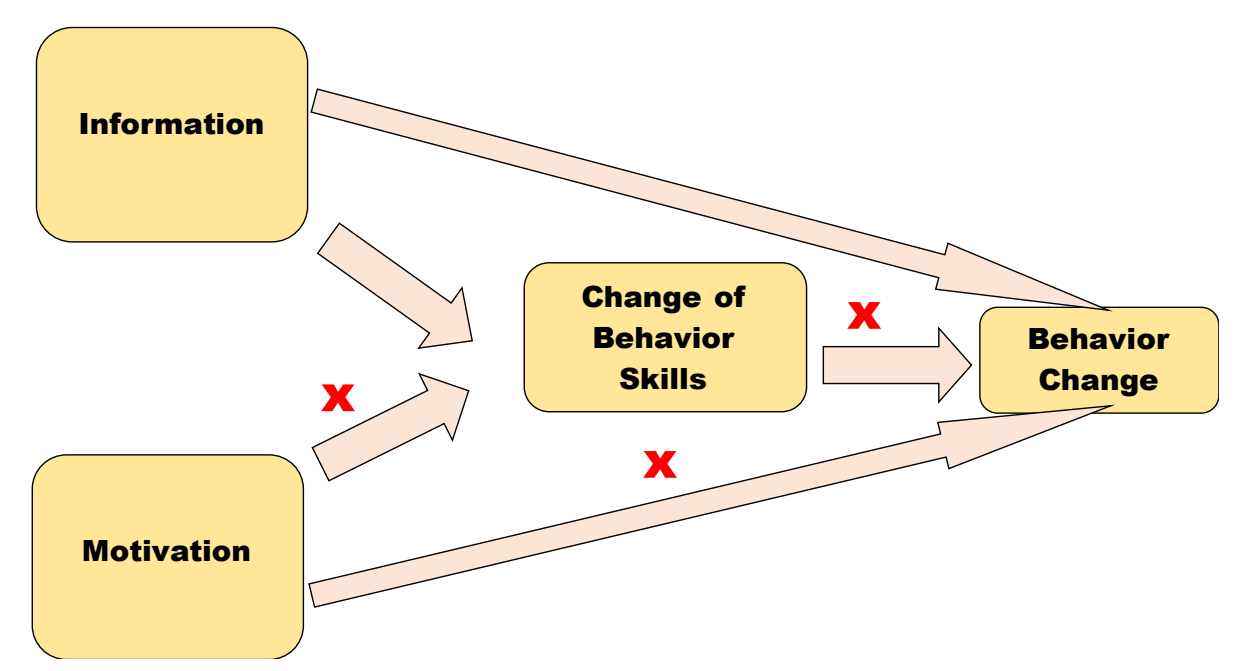

Figure 1 Behavior Change Diagram Based on Information-Motivation-Behavioural Skills Model (IMB) Theory

Insignificant result of behavior change could possibly due to inconsistency of motivation in face-to-face group.

dietary behavior based on HDI, BMI, waist circumference, and cardiovascular risk profile on all groups. All of these results seems to be caused by lack of knowledge acceptance (in face-to-face group) and motivation (in other groups). Similar results found on some previous studies, which showed that lifestyle promotion program in workplace did not reduce body weight and waist circumference on men. ${ }^{13}$ Pelletier stated that studies who did not produce significant results tend to be not published, and this may resulted on publication bias. ${ }^{14}$ Other studies revealed that reducing body weight significantly did not give any outcome on improving cardiovascular risk profile..$^{15,16}$

According to a study conducted by Racette et al., multicomponent intervention for one year including seminars, team competitions, rewards, group exercise classes, dietary, and healthy diet intervention could reduce BMI and also significantly improve blood pressure, total cholesterol, HDL and LDL cholesterol, and Framingham Risk Score $(\mathrm{p} \leq 0.05)$. However, in assessment-only group, those improvements also occurred on all parameters except for Framingham Risk Score. ${ }^{17}$ This showed that a long assessment, a year in this case, could possibly be the key to achieve cardiovascular risk parameters improvement, and this require further investigation.

Studies show that multicomponent, life-style modification education including behavior therapy, e.g. dietary recommendations, diet portion control, self-monitoring, stimulus control, social support, and goals for more than 6-12 months intervention were effective. ${ }^{18,19}$ In the study conducted by Salinardi et al., sort of intervention reduced weight significantly compared to control group ( $-8.0 \pm 0.7$ vs $+0.9 \pm 0.5$

Table 2 Comparison Analysis of Cardiovascular Risk Profile Before and After Education

\begin{tabular}{lcccc}
\hline & Face-to-face & Recorder & $\begin{array}{c}\text { Combination } \\
\text { (1 time face-to-face) }\end{array}$ & $\begin{array}{c}\text { Combination } \\
\text { (2 times face-to-face) }\end{array}$ \\
\hline Asymp. Sig & 0.046 & 0.157 & 1.000 & 0.317 \\
(2-tailed) & 0.317 & 0.564 & 0.157 & 0.317 \\
& 0.083 & 1.000 & 1.000 & 0.317 \\
& 0.317 & 1.000 & 0.317 & 0.317 \\
\hline
\end{tabular}


$\mathrm{kg}$, respectively; $\mathrm{p}<0.001$ ), and also reduced fasting total cholesterol, glucose, systolic and diastolic blood pressure significantly $(p<0.02) .{ }^{19}$ Furthermore, longer term intervention and multicomponent program is needed to succeed body weight reducing program because more complex education need to be done step by step. Other studies including behavioral therapy also support this treatment more effectively than education alone, ${ }^{20-22}$ suggesting that in order to improve weight and cardiovascular parameters, long-term (6-12 months), multicomponent intervention including behavior therapy to overcome low motivation, may result in greater outcome.

This study has some limitations, that is, sample size is too small for each group and direct interview by nutritionist only done twice; before and after education. Other than that, this study did not assess the environment and genetic status of subjects, by which can contribute to health status. Further research is needed to overcome those limitations.

\section{Conclusion}

Lifestyle modification education can increase patients' knowledge significantly on face-toface session group, but not on recorder and combination groups. Lifestyle modification education did not give any significant impact on dietary behavior based on HDI, BMI, waist circumference, and cardiovascular risk profile on all groups. Long term intervention and multicomponent program including behavior therapy may be needed to improve lifestyle changes and reduce cardiovascular risk.

\section{Acknowledgement}

We thank Dian Handayani, S.KM., M.Kes, Ph.D., and Dr. Sri Adiningsih, dr., M.S., MCN from Airlangga University for the support as our obesity educator. Last but not least, we thank Institute for Research and Community
Services of University of Surabaya for their guidance and for making this research possible to imply.

\section{Funding}

This research was funded by the Ministry of Research, Technology and Higher Education of the Republic of Indonesia through desentralisation grant program, on April-November 2014.

\section{Conflict of Interest}

The authors declared no potential conflicts of interest with respect to the research, authorship, and publication of this article.

\section{References}

1. Pi-Sunyer X. The medical risks of obesity. Postgrad Med. 2009;121(6):21-33. doi: 10. 3810/pgm.2009.11.2074.

2. Research and Health Development of Ministry of Health of the Republic of Indonesia. Basic health research. Jakarta: Ministry of Health of the Republic of Indonesia; 2013.

3. World Health Organization (WHO). Noncommunicable diseases country profiles. France: World Health Organization; 2011.

4. Bray GA, Bouchard C. Handbook of obesity: Clinical applications, $3^{\text {rd }}$ Ed. New York: Informa Healthcare USA, Inc; 2008.

5. Choi B, Schnall PL, Yang H, Dobson M, Landsbergis P, Israel L, et al. Sedentary work, low physical job demand, and obesity in US workers. Am J Ind Med. 2010;53(11): 1088-101. doi: 10.1002/ajim.2086

6. Schulte PA, Wagner GR, Ostry A, Blanciforti LA, Cutlip RG, Krajnak KM, et al. Work, obesity, and occupational safety and health. Am J Public Health. 2007;97 (3):428-36. doi: 10.2105/AJPH.2006.086 900

7. Wadden TA, Webb VL, Moran CH, Bailer 
BA. Lifestyle modification for obesity: New developments in diet, physical activity, and behavior therapy. Circulation. 2012; 125(9):1157-70. doi: 10.1161/CIRCULA TIONAHA.111.039453.

8. Yamauchi K, Katayama T, Yamauchi T, Kotani K, Tsuzaki K, Takahashi K, et al. Efficacy of a 3-month lifestyle intervention program using a Japanese-style healthy plate on body weight in overweight and obese diabetic Japanese subjects: A randomized controlled trial. Nutr J. 2014;13:108. doi: 10.1186/1475-2891-13-108.

9. Donnelly JE, Smith BK, Dunn L, Mayo MM, Jacobsen DJ, Stewart EE, et al. Comparison of a phone vs clinic approach to achieve $10 \%$ weight loss. Int $\mathrm{J}$ Obes (Lond). 2007;31(8):1270-6. doi: 10.1038 /sj.ijo.0803568

10. Spahn JM, Futagawa V, Ramos L, Myers EF. Using the diet readiness test to triage clients for nutrition education. J Am Diet Assoc. 1996;96(9):A31. doi: 10.1016/S00 02-8223(96)00416-6

11. D’Agostino RB, Vasan RS, Pencina MJ, Wolf PA, Cobain M, Massaro JM, et al. General cardiovascular risk profile for use in primary care: The Framingham Heart Study. Circulation. 2008;117(6):743-53. doi: 10.1161/CIRCULATIONAHA.107.6995 79

12. Chang SJ, Choi S, Kim S-A, Song M. Intervention strategies based on information-motivation-behavioral skills model for health behavior change: A systematic review. Asian Nurs Res. 2014; 8(3):172-81. doi: 10.1016/j.anr.2014.08. 002

13. Appukutty M, Karim N, Daud Z, Don R, Noor M. Workplace health promotion for preventing and managing obesity: Results from 6 months intervention. Obes Rev. 2014; 15(S2):223.

14. Pelletier KR. A review and analysis of the clinical and cost-effectiveness studies of comprehensive health promotion and disease management programs at the worksite: Update VII 2004-2008. J Occup Environ Med. 2009;51(7):822-37. doi: 10. 1097/JOM.0b013e3181a7de5a.

15. Anderson LM, Quinn TA, Glanz K, Ramirez G, Kahwati LC, Johnson DB, et al. The effectiveness of worksite nutrition and physical activity interventions for controlling employee overweight and obesity. Am J Prev Med. 2009;37(4):340-57. doi: 10.1016/j.amepre.2009.07.003.

16. Ferdowsian HR, Barnard ND, Hoover VJ, Katcher HI, Levin SM, Green AA, et al. A multicomponent intervention reduces body weight and cardiovascular risk at a GEICO corporate site. Am J Health Promot. 2010;24(6):384-7. doi: 10.4278/ajhp.081 027-QUAN-255.

17. Racette SB, Deusinger SS, Inman CL, Burlis TL, Highstein GR, Buskirk TD, et al. Worksite Opportunities for Wellness (WOW): Effects on cardiovascular disease risk factors after 1 year. Prev Med. 2009; 49(2-3):108-14. doi: 10.1016/j.ypmed.20 09.06.022

18. Weerasekara YK, Roberts SB, Kahn MA, LaVertu AE, Hoffman B, Das SK. Effectiveness of workplace weight management interventions: A systematic review. Curr Obes Rep. 2016;5(2):298306. doi: 10.1007/s13679-016-0205-z.

19. Salinardi TC, Batra P, Roberts SB, Urban LE, Robinson LM, Pittas AG, et al. Lifestyle intervention reduces body weight and improves cardiometabolic risk factors in worksites. Am J Clin Nutr. 2013; 97(4):667-76. doi: 10.3945/ajcn.112.046 995

20. Jovanović Z, Crncević-Orlić Z, Stimac D, Kokić S, Persić V, Ruzić T, et al. Effects of obesity reduction on cardiovascular risk factors: Comparison of individual and group treatment--substudy of the Croatian Healthy Weight Loss Programme. Coll 
Antropol. 2009;33(3):751-7.

21. Earnest CP, Church TS. Evaluation of a voluntary worksite weight loss program on metabolic syndrome. Metab Syndr Relat Disord. 2015;13(9):406-14. doi: 10. 1089/met.2015.0075.
22. Thorndike AN. Workplace interventions to reduce obesity and cardiometabolic risk. Curr Cardiovasc Risk Rep. 2011;5(1): 79-85. 